\title{
Incidental detection of asymptomatic pneumothorax resulting in a diagnosis of Birt-Hogg-Dubé syndrome
}

\author{
Keigo Kobayashi ${ }^{\odot}$
}

Division of Pulmonary Medicine, Department of Medicine, Keio University School of Medicine, Tokyo, Japan

\section{Correspondence to} Dr Keigo Kobayashi, keigokbys@gmail.com

Accepted 10 January 2019

\section{DESCRIPTION}

A 35 -year-old Japanese woman visited our hospital with a pneumothorax incidentally detected in a health screening. Chest radiography revealed slight pneumothorax in the right lung. She was asymptomatic, with $99 \%$ oxygen saturation in room air, and no history of smoking and no renal tumours or fibrofolliculomas. However, her father and sister also had a pneumothorax.

Although the pneumothorax was small, chest CT was performed, which revealed multiple thinwalled, variable-sized lung cysts with round, oval and irregular shapes, present bilaterally with lower and medial lung predominance (figure $1 \mathrm{~A}, \mathrm{~B}$ ). The largest cyst in the right lower lobe contacting the heart was seen abutting or including the proximal portion of the pulmonary vein or artery (figure 1A). These findings are common in Birt-Hogg-Dubé (BHD) syndrome. ${ }^{1}$ Genetic analysis of her blood revealed a c. 1285 dupC frameshift mutation in the folliculin (FLCN) gene, consistent with a diagnosis of BHD syndrome.

BHD syndrome is a rare autosomal dominant disorder caused by mutation of germline FLCN mapped in the chromosome $17 \mathrm{p} 11.2$ region. It is characterised by fibrofolliculomas, early-onset renal cancers and spontaneous pneumothoraxes caused by lung cysts. The risk of pneumothorax is considerable in patients aged 20-40 years. Lung cysts on chest CT have been described in up to $90 \%$ of patients, with a corresponding 50 -fold greater risk of pneumothorax than that in the normal population. ${ }^{2}$ A causative gene, FLCN and its interacting partners, FNIP1 and FNIP2, cooperatively play important roles in metabolic pathways including AMP-activated protein kinase-mediated energy AMPK-mediated energy sensing, mTORC1-dependent cell proliferations and Ppargc1a-driven
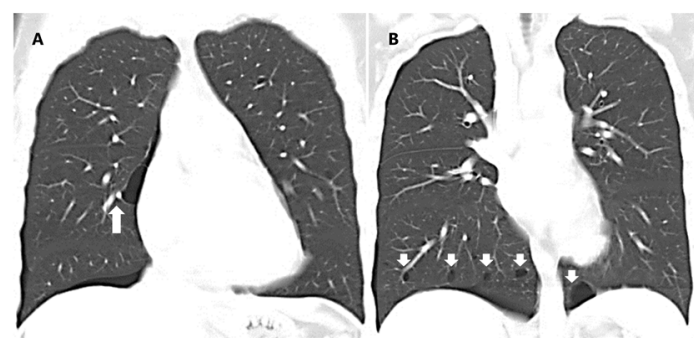

Figure 1 Coronal chest CT images. (A) The largest cyst is seen abutting or including the proximal portion of the pulmonary vein or artery (arrow). (B) The lung cysts show a basal distribution (arrow). mitochondrial oxidation; the dysregulation of these metabolic pathways triggers aberrant kidney cell proliferations and renal tumourigenesis. ${ }^{4}$ Therefore, early diagnosis is critical for systematic screening for renal cancers, because of its sevenfold higher risk in these patients, which can lead to a poor prognosis, ${ }^{5}$ and to refer patients for early genetic counselling and personalised follow-up.

In this case, it was important to perform chest CT, which confirmed a diagnosis of BHD syndrome. Hence, we recommend that physicians perform chest CT at the time of pneumothorax examination in patients with a family history of pneumothorax.

\section{Learning points}

- Birt-Hogg-Dubé (BHD) syndrome is a rare autosomal dominant disorder and early diagnosis is critical for systematic screening for renal cancers, which can lead to a poor prognosis.

- Lung cysts that can lead to spontaneous pneumothoraxes are the characteristic features of BHD syndrome, but may not always be detected by a chest $\mathrm{X}$-ray examination.

- We recommend that physicians perform chest $\mathrm{CT}$ at the time of pneumothorax examination in patients with a family history of pneumothorax.

Contributors KK drafted the manuscript and was responsible for patient care.

Funding The author has not declared a specific grant for this research from any funding agency in the public, commercial or not-for-profit sectors.

Competing interests None declared.

Patient consent for publication Not required.

Provenance and peer review Not commissioned; externally peer reviewed.

\section{REFERENCES}

1 Tobino K, Gunji Y, Kurihara M, et al. Characteristics of pulmonary cysts in Birt-Hogg-Dubé syndrome: thin-section CT findings of the chest in 12 patients. Eur J Radiol 2011;77:403-9.

2 Menko FH, van Steensel MA, Giraud S, et al. Birt-HoggDubé syndrome: diagnosis and management. Lancet Oncol 2009;10:1199-206.

3 Kunogi M, Kurihara M, Ikegami TS, et al. Clinical and genetic spectrum of Birt-Hogg-Dube syndrome patients in whom pneumothorax and/or multiple lung cysts are the presenting feature. J Med Genet 2010;47:281-7.

4 Hasumi H, Baba M, Hasumi Y, et al. Birt-Hogg-Dubé syndrome: clinical and molecular aspects of recently identified kidney cancer syndrome. Int J Urol 2016;23:204-10.

5 Zbar B, Alvord WG, Glenn G, et al. Risk of renal and colonic neoplasms and spontaneous pneumothorax in the Birt-Hogg-Dubé syndrome. Cancer Epidemiol Biomarkers Prev 2002;11:393-400. 
Copyright 2019 BMJ Publishing Group. All rights reserved. For permission to reuse any of this content visit https://www.bmj.com/company/products-services/rights-and-licensing/permissions/

BMJ Case Report Fellows may re-use this article for personal use and teaching without any further permission.

Become a Fellow of BMJ Case Reports today and you can:

- Submit as many cases as you like

- Enjoy fast sympathetic peer review and rapid publication of accepted articles

Access all the published articles

- Re-use any of the published material for personal use and teaching without further permission

For information on Institutional Fellowships contact consortiasales@bmjgroup.com

Visit casereports.bmj.com for more articles like this and to become a Fellow 